\title{
Virulence Gene Profile and Serogroups of STEC in Diarrhoeic Buffalo Calves
}

\author{
M. Srivani ${ }^{1 *}$, Y. Narasimha Reddy ${ }^{2}$, K.V. Subramanyam ${ }^{3}$, \\ M. Lakshman ${ }^{4}$, T. Srinivasa Rao ${ }^{5}$ and K.L. Kavitha ${ }^{1}$ \\ ${ }^{1}$ Department of Veterinary Microbiology, NTR College of Veterinary Science, \\ Gannavaram, Krishna District, Andhra Pradesh, India \\ ${ }^{2}$ Department of Veterinary Microbiology, ${ }^{4}$ Roska lab, College of Veterinary Science, \\ Rajendranagar, Rangareddy District, Telangana State, India \\ ${ }^{3}$ Department of Veterinary Microbiology, College of Veterinary Science, \\ Proddatur, Andhra Pradesh, India \\ ${ }^{5}$ Department of Veterinary Public Health, NTR College of Veterinary Science, \\ Gannavaram, Krishna District, Andhra Pradesh, India \\ *Corresponding author
}

\begin{tabular}{|l|}
\hline \multicolumn{1}{|l}{} \\
\hline Ke y w o r d s \\
Epidemiology, \\
Diarrhoiec Buffalo \\
calves, STEC, \\
Serogroups \\
\hline Article Info \\
\hline Accepted: \\
18 August 2020 \\
Available Online: \\
10 September 2020 \\
\hline \hline
\end{tabular}

\section{A B S T R A C T}

A study was undertaken to investigate virulence gene profiles of shiga toxinproducing E. coli serogroups in diarrhoeic buffalo calves of Andhra Pradesh (AP) and Telangana States (TS). A total of 375 faecal samples from diarrhoeic buffalo calves of 1 to 90 days were collected from various districts in AP and TS, of which 302 E. coli $(80.53 \%)$ were isolated. The virulence genes of STEC were detected using multiplex PCR and serogrouping was carried at National Salmonella and Escherichia centre, Central research institute, Kasauli, Himachal Pradesh. Among the virulence genes of STEC the stxl, stx $2 \&$ hlyA genes carrying isolates constitutes about $4.63 \%$ of which $36 \%$ were identified as O157, distributed in Krishna and West Godavari districts of Andhra Pradesh. The serogrops of STEC associated with calf diarrhoeia includes O8, O9, O10, O26, O29, O49, O84, O86, O120, O121, O125, O126, O128, O141 and O157. The present study concluded that diarrhoeic buffalo calves are the source of about 15 STEC serogroups including $\mathrm{O} 157$ and $\mathrm{O} 26$ which are having public health significance.

\section{Introduction}

Escherichia coli is an important enteric pathogen of buffalo calves causing neonatal diarrhoea and economic loss to the dairy producers. Epidemiological studies of cattle and water buffalo calves have revealed that $E$. coli was the major cause of neonatal diarrhoea 
(Fagiolo et al., 2005 and Foster and Smith, 2009). Shiga toxin-producing Escherichia coli (STEC) are one of six different categories of diarrhoeagenic $E$. coli recognized so far. STEC has been implicated as an etiological factor of calf diarrhea, (Sandhu and Gyles, 2002) and cattle are regarded as the main reservoirs of STEC which produce Shiga toxins (Stx1 and Stx2) encoded by stxl and stx2 genes (Boerlin et al., 2005). The other virulence factors of STEC are intimin and enterohaemolysin encoded by eae and ehxA variants of stx 1 and more than 20 variants of stx2 have genes respectively (Blanco et al., 2004). Different serotypes of STEC that were associated with diarrhoea in calves (manly $\mathrm{O} 5, \mathrm{O} 26$, and $\mathrm{O} 118$ ) have been recognized (Orden et al., 2003) Therefore, studying the prevalence of various serogroups of STEC in buffalo calves in this geographic area is important to monitor the epidemiology of infection due to $E$. coli associated calf diarrhoea.

\section{Materials and Methods}

A total of 375 faecal samples from diarrhoeic buffalo calves of 1 to 7, 8-30, 31-60 and 6190 day age groups were collected randomly from organized dairy farms and individual farmers of Vizianagaram, Vishakapatnam, East Godavari, West Godavari, Krishna, Guntur, Prakasam, Districts of Andhra Pradesh State and Ranga Reddy and Khammam Districts of Telangana State. Geographical distribution and age of diarrhoeic calves were recorded during sampling. Fecal samples were collected using sterile rectal swabs. After collection, the swabs were immediately transported to the department of Veterinary Microbiology, NTR College of Veterinary Science, Gannavaram in ice-cooled containers for $E$. coli isolation. All the samples were inoculated on to Maconkey agar and incubated at $37^{\circ} \mathrm{c}$ for 24 hours. The pink colonies obtained were again inoculated in EMB agar and the colonies showing green metallic sheen were selected and confirmed as E. coli by standard biochemical tests (Cruickshank 1970). Bacterial DNA was obtained by boiling the cells at $100^{\circ} \mathrm{C}$ for $15 \mathrm{~min}$ and then pelleting the cells by centrifugation. The supernatant was then used in the PCR reaction.

\section{Molecular Characterization of $E$. coli isolates}

The biochemical results were confirmed by PCR amplification using E. coli 16s rRNA specific primers quoted by Sun Dong-bo et al. (2011)

(E16S-F: ATCAACCGAGATTCCCCCAGT E16S-R: TCACTATCGGTCAGTCAGGAG) with 231 bp amplified product.

\section{PCR conditions for detection E.coli 16SrRNA}

PCR reactions were carried out in an Eppendorf thermal cycler. The amplification conditions were $5 \mathrm{~min}$ of denaturation at $95^{\circ} \mathrm{C}$, followed by 35 cycles of $95^{\circ} \mathrm{C}$ for 1 min, $50^{\circ} \mathrm{C}$ for $50 \mathrm{~s}$, and $72^{\circ} \mathrm{C}$ for $1 \mathrm{~min}$, and a final extension step of $72^{\circ} \mathrm{C}$ for $10 \mathrm{~min}$. DNA amplified by PCR was subjected to $2 \%$ agarose gel electrophoresis as described by sambrook and Russel (2001).

The primers used in the present study for the detection of shiga toxin producing E. coli were as described by Paton and Paton (1998) (Table 1)

Standardization of multiplex PCR protocol for detection of stx 1 , stx 2 , eaeA, hlyA virulence genes

PCR for amplification of the stx 1 , st $x 2$, eaeA, hlyA genes was set up in $25 \mu l$ reaction. Following initial trails with varying concentration of components the reaction mixture was optimized as below 
Primer F (20 p mol)

Primer R (20 p mol)

Master mix

Template

NFW water

Total

PCR tube containing the reaction mixture was flash spun in a microcentrifuge to settle the reactants at the bottom. PCR assay was performed in Eppendorf thermocycler with heated lid. Samples were subjected to 35 cycles as per the procedure of paton and paton (1998). The cycle consisting of one min of denaturation at $95^{\circ} \mathrm{C}$, two min of annealing at $65^{\circ} \mathrm{C}$ and $1.5 \mathrm{~min}$ of elongation at $72^{\circ} \mathrm{C}$ for the first 10 cycles, decrementing annealing temperature to $60^{\circ} \mathrm{C}$ by cycle 15 , one min of denaturation at $95^{\circ} \mathrm{C}$, two min of annealing at $60^{\circ} \mathrm{C}$ and $1.5 \mathrm{~min}$ of elongation at $72^{\circ} \mathrm{C}$, incrementing to $2.5 \mathrm{~min}$ from cycles 26 to 35 . On completion of the reaction, tubes with PCR products were held at $4{ }^{\circ} \mathrm{C}$. DNA amplified by PCR was subjected to $2 \%$ agarose gel electrophoresis as described by sambrook and Russel (2001).

\section{Serogrouping of $E$. coli isolates}

The isolates of $E$. coli were sent to National Salmonella and Escherichia centre, Central research institute, Kasauli, Himachal Pradesh on nutrient agar slants for serogrouping.

\section{Results and Discussion}

Out of 375 faecal samples collected from diarrhoeic buffalo calves, 302 (80.53\%) samples were found positive after biochemical and molecular characterization for E. coli. Among different age groups, highest rate $(85.04 \%)$ of $E$. coli isolated from faecal samples of 1-7 day old buffalo calves, followed by 83.96, 63.27 and 50.00\% isolated from 8-30, 31-60 and 61-90 day old buffalo calves, respectively. Similar to present findings, higher prevalence $(70 \%)$ was observed in buffalo calves of less than 4 weeks age (Borriello et al., (2012). Compared to the prevalence rate observed in this study, lower prevalence rate of $E$. coli was reported in diarrhoeic buffalo calves by Deepti Naag et al., (2015) in Jabalpur, India (59.37\%), Abdulgayeid et al., (2015) and Helal et al., (2014) in Egypt (66 and 72\%), Anwarullah et al., (2014) in Pakistan(14.6\%), Paul et al., (2010) and Islam et al., (2008) in Bangladesh (45 and 37.9\%) and in healthy buffalo calves (Helal et al., 2014) in Egypt. On the other hand, higher prevalence $(95.6 \%)$ of $E$. coli in buffaloes was also reported by Raghavendra et al., (2016) in Uttar Pradesh, India. The differences of the prevalence rates of $E$. coli may be attributed to the geographical locations and management practices as well as hygienic measures which influence the susceptibility of calves to $E$. coli infection (Cho and Yoon, 2014 and Içen et al., 2013).

In Andhra Pradesh, highest prevalence of $E$. coli in diarrhoeic buffalo calves was observed in Krishna district (95.58) and lowest (62.5\%) was found in Vizianagaram district while in Telangana state prevalence was high in Khammam (76\%) compared to Ranga Reddy district $(62.85 \%)$.

The Association between virulence genes and serogroups of STEC in diarrhoeic buffalo calves is presented in Table 2 .

Among the E. coli isolates from diarrhoeic buffalo calves, $35.01 \%$ isolates were STEC and the isolates carrying virulence genes of eaeA\& hlyA combination were highest (45\%). This was in accordance with the findings of Islam et al., (2008) who detected $37.9 \%$ STEC mostly eae positive in faecal samples of buffaloes in Bangladesh (Table 2). 
Table.1 Details of the primers used for the detection of stx1, stx2, eaeA and hlyA genes

\begin{tabular}{|c|c|c|c|c|}
\hline S.NO & Primer & Sequence (5'---- 3') & $\begin{array}{l}\text { Target } \\
\text { gene }\end{array}$ & $\begin{array}{l}\text { Expected Amplicon } \\
\text { size (bp) }\end{array}$ \\
\hline \multirow[t]{2}{*}{1} & Stx $1 \mathrm{~F}$ & ATAAATCGCCATTCGTTGACTAC & \multirow[t]{2}{*}{ stx 1} & \multirow[t]{2}{*}{180} \\
\hline & Stx2 R & AGAACGCCCACTGAGATCATC & & \\
\hline \multirow[t]{2}{*}{2} & Stx $2 \mathrm{~F}$ & GGCACTGTCTGAAACTGCTCC & \multirow[t]{2}{*}{$s t x 2$} & \multirow[t]{2}{*}{254} \\
\hline & Stx2 R & TCGCCAGTTATCTGACATTCTG & & \\
\hline \multirow[t]{2}{*}{3} & eaeA F & GACCCGGCACAAGCATAAGC & \multirow[t]{2}{*}{ eaeA } & \multirow[t]{2}{*}{384} \\
\hline & eae $\mathrm{R}$ & CCACCTGCAGCAACAAGAGG & & \\
\hline \multirow[t]{2}{*}{4} & hlyA F & GCATCATCAAGCGTACGTTCC & \multirow[t]{2}{*}{ hlyA } & \multirow[t]{2}{*}{534} \\
\hline & hlyA R & AATGAGCCAAGCTGGTTAAGCT & & \\
\hline
\end{tabular}

Table.2 Association between virulence genes and serogroups of STEC in diarrhoeic buffalo calves

\begin{tabular}{|l|l|l|l|}
\hline Virulence gene & $\mathbf{n = 3 0 2}$ & $\mathbf{\%}$ & Serogroups \\
\hline stx1 & 17 & 5.62 & O8 (4), O121(4), O9 (2), O26 (2) and UT (5) \\
\hline stx2 & 13 & 4.30 & O29 (4), O125 (3), O10(2), O8 (1) and UT (3) \\
\hline stx1,stx2 \& hlyA & 14 & 4.63 & O128 (5), O157 (5) and O9 (4) \\
\hline stx1,eaeA \& hlyA & 10 & 3.31 & O26 (5) and O120 (5) \\
\hline stx1\& hlyA & 7 & 2.31 & O125 (4) and O86 (3) \\
\hline eaeA\& hlyA & 45 & 14.90 & $\begin{array}{l}\text { O84 (13), O128 (10), O126 (6), O141(5), O49 } \\
(2), \text { O121(2) and UT(7) }\end{array}$ \\
\hline
\end{tabular}

Fig.1 Amplified product of 16S r RNA

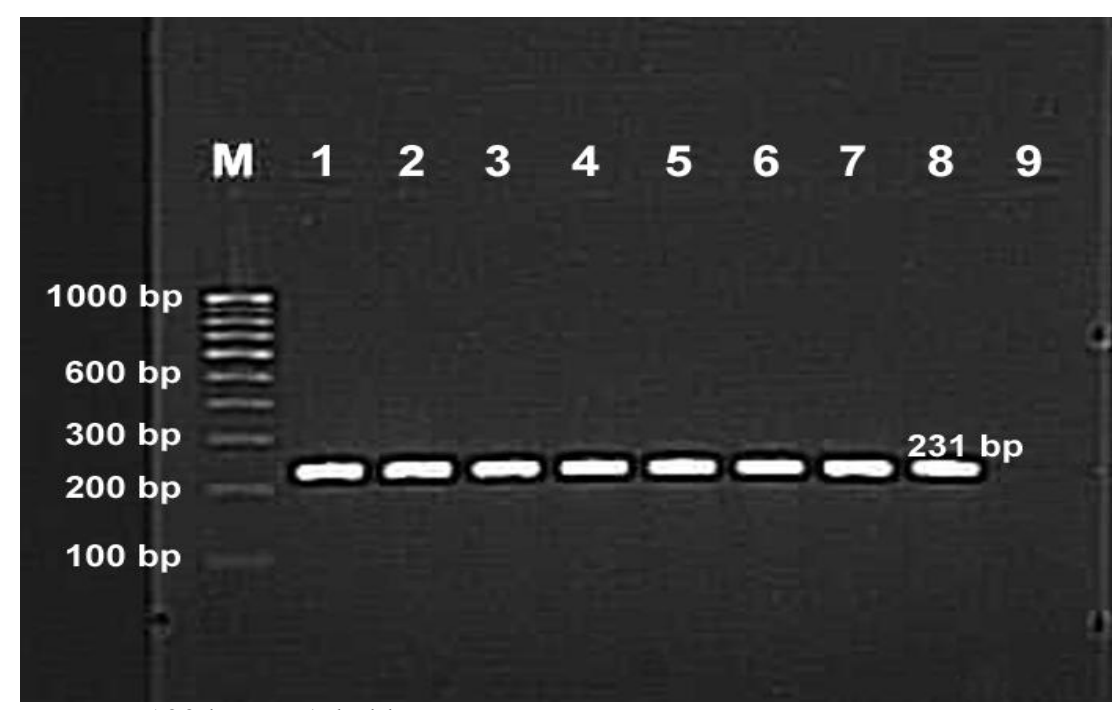

Lane M: 100 bp DNA ladder

Lane 1: E. coli $16 \mathrm{~S}$ r RNA positive control

Lane 2 to $8: E$. coli isolates carrying $16 \mathrm{~S}$ r RNA gene

Lane 9: Negative control. 
Fig.2 Multiplex PCR for detecting Shiga toxin genes. Stx1 (180bp), Stx2 (254bp) eaeA (384bp), hlyA (534bp) genes

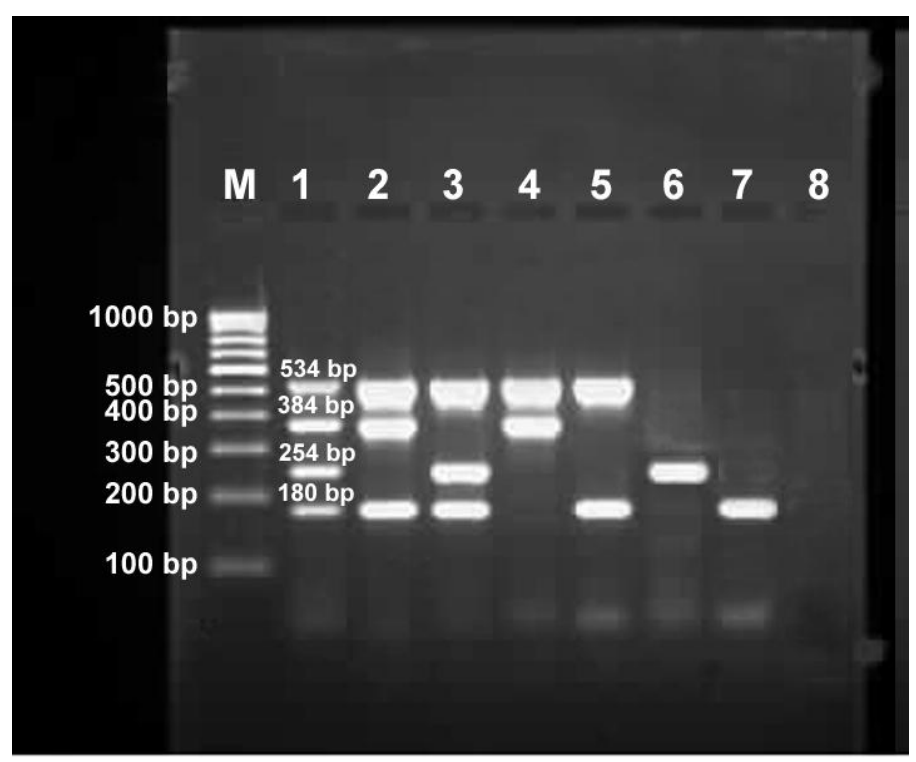

Lane M: 100 bp DNA ladder

Lane 1: E. coli positive control carrying all four genes Lane 2 to 7: $E$. coli isolates carrying shiga toxin genes Lane 8: Negative control.

The serogroups of STEC associated with calf diarrhoeia includes O8, O9, O10, O26, O29, O49, O84, O86, O120, O121, O125, O126, O128, O141 and O157. Among these serogroups, the frequency of O128, O8, O121, O9, O126 and O125 were high compared to other serogroups identified (Table 2). The stxl, stx $2 \&$ hlyA genes carrying isolates constitutes about $4.63 \%$ of which $5(36 \%)$ were identified as 0157 which is known for its zoonootic significance. The World Health Organization also recognizes $\mathrm{O} 26$ as having the potential to cause severe disease in humans (WHO, 1995). The present study also observed that $50 \%$ of stx, eaeA \& $h l y A$ and $12 \%$ of stx 1 genes carrying isolates detected as $\mathrm{O} 26$.

Parallel to the present findings $42.5 \%$ prevalence of $\mathrm{O} 157$ in buffalo calves recorded in Italy (Sandra et al., 2010). In a similar study the incidence of $14.4 \%$ of the serotype O157 was reported from the STEC isolates carrying eae positive genes in buffaloes of
Bangladesh (Islam et al., 2008) while in Italy adult water buffalo has been reported as a natural reservoir of the serotype $\mathrm{O} 157$ (Galiero et al., 2005). Consistent with present findings, $\mathrm{O} 9$ serogroup in diarrhoeic mithun calves in Nagaland (Rajkhowa et al., 2009) and 086 serogroup in diarrhoeic calves in Brazil (Rigobelo et al., 2006) reported. Toni et al., (2006) also recognized $\mathrm{O} 8$ and $\mathrm{O} 9$ serogroups in diarrhoeic pre-weaned piglets. Contrary to the present findings, Vagh and Jani (2010) detected serotype O56 was highest $(14.28 \%)$ in diarrhoeic buffalo calves in Gujarat (Fig. 1 and 2).

The present study detected the prevalence of STEC serogroups that are having public health significance like $\mathrm{O} 157$ in Krishna and West Godavari districts and $\mathrm{O} 26$ in Vishakhapatnam, East Godavari, West Godavari, Guntur districts of Andhra Pradesh and Khammam district of Telangana state. Therefore, the diarrhoec buffalo calves may be the potential source of these serogroups 
which are having zoonootic importance in this geographis area.

\section{Acknowledgements}

The authors are thankful to the Sri Venkateswara Veterinary University, Tirupati, for providing necessary funds and facilities to carry out the present research work

\section{References}

Abdulgayeid, M., Hazem Shahin., Seham Foad and Madiha, S., Ibrahim. (2015). Molecular characterization of Escherichia coli isolated from buffalo calves in El-Behera Governorate. Alexandria Journal of Veterinary Sciences, 47 (1): 90-96.

Anwarullah, M., Khan, J, A., Khan, M.S.K., Ashraf, K., and Avais, M. (2014). Prevalence of Salmonella and Escherichia coli associated diarrhea in buffalo and cow calves. Buffalo Bulletin, 33(3): 332-336.

Blanco, M., Blanco, J.E., Mora A., Dahbi, G., Alonso, M.P., Gonzalez, E.A., Bernardez, M.I., Blanco, J. (2004). Serotypes, virulence genes, and intimin types of Shiga toxin (verotoxin)producing Escherichia coli isolates from cattle in Spain and identification of a new intimin variant gene (eae-xi). Journal of Clinical Microbiology, 42:645-5.

Boerlin, P., Rebeccah, T., Carlton, L.G., Richard, R.S., Nicol, J., Heather, L., Nicholson, V., Scott, A., McEwen, Robert, F., and Marie A. (2005). Antimicrobial resistance and virulence genes of Escherichia coli isolates from swine in Ontario. Applied and Environmental Microbiology 71(11): 6753-6761.

Borriello, G., Lucibelli, M. G., De Carlo, E.,
Auriemma, C., Cozza, D., Ascione, G., Scognamiglio, F., Iovane, G., and Galiero, G. (2012) Characterization of enterotoxigenic E. coli (ETEC), Shigatoxin producing E. coli (STEC) and necrotoxigenic $E$. coli (NTEC) isolated from diarrhoeic Mediterranean water buffalo calves (Bubalus bubalis). Research in Veterinary Science 93(1): 18-22.

Cho, Y and Yoon K.J. (2014). An overview of calf diarrhea-infectious etiology, diagnosis, and intervention. Journal of Veterinary Science 15(1):1-17.

Cruickshank, R. (1970) Medical Microbiology. 11th ed. The English Language Book Society E and Livingston Ltd., Edinburgh.

Deepti Naag., Madhu Swamy., and Shrivastav, A.B., (2015). Detection of verotoxin producing strain of E.coli in buffalo calves. Buffalo Bulletin, 34 (2): 227- 229.

Fagiolo, A., Roncoroni, C., Lai, O., Borghese, A., (2005). Buffalo Pathologies. In:Borghese, A. (Ed.), Buffalo Production and Research. FAO Regional Office for Europe Inter Regional Cooperative Research Network on Buffalo, Rome, pp. 249296.

Foster, D.M., Smith, G.W., (2009). Pathophysiology of diarrhea in calves. Veterinary Clinics of North America: Food Animal Practice 25, 13-36.

Galiero, G., Conedera, G., Alfano, D., Caprioli, A., (2005). Isolation of verocytotoxin producing Escherichia coli 0157 from water buffaloes (Bubalus bubalis) in Southern Italy. Veterinary Record 156, 382-383.

Helal, A.D., Hanan, E., Nagib., Abdel Samea, M.E., and Abdel Fattaiah, S.H.M. (2014). Using of traditional and quantitative cytochmecal methods of identification and enzyme 
characterization of some E.coli serogroups using entiritis in buffaloes. Assiut Veterinary Medical Journal 60 (142): 121-131.

Içen, H., Arserim, N.B,, Işik, N., Özkan, C., and Kaya, A. (2013). Prevalence of four enteropathogens with immunochromatographic rapid test in the feces of diarrheic calves in east and southeast of Turkey. Pakistan Veterinary Journal 33(4): 496-499.

Islam, M.A., Mondol, A.S., de Boer, E., Beumer, R.R., Zwietering, M.H., Talukder, K.A. and Heuvelink Annet, E. (2008). Prevalence and genetic characterization of Shiga toxinproducing Escherichia coli isolates from slaughtered animals in Bangladesh. Applied and Environmental Microbiology 74(17): 5414-5421.

Orden Yuste, M., Cid, D., Piacesi, T., Martinez, S., Ruiz-Santa-Quiteria, J.A., De la Fuente. (2003). Typing of the eae and espB genes of attaching and effacing Escherichia coli isolates from ruminants. Veterinary Microbiology. 96(2): 203-15.

Paton, A.W., and Paton, J.C. (1998). Detection and characterization of Shiga toxygenic Escherichia coli by using multiplex PCR assays for stxl, stx2, eaeA, enterohemorrhagic E. coli hlyA, rfbO111, and rfbO157. Journal of Clinical Microbiology 36 (2): 598-602.

Paul, S.K, Khan, M.S.R., Rashid, M.A,. Hassan, J.. Mahmud, S.M.S. (2010). Isolation and characterization of Escherichia coli from buffalo calves in some selected areas of Bangladesh Bangladesh Journal of Veterinary Medicine 8(1): 23-26.

Raghavendra, P.M., Udit Jain., Basanti Bist., Amit Kumar Verma., and Ashok Kumar. (2016). Prevalence of vero toxic Escherichia coli in fecal samples of domestic as well as wild ruminants in
Mathura districts and Kanpur zoo. Veterinary World 9(1): 71-74

Rajkhowa, S., Hussain, I., and Rajkhowa., C. (2009). Detection of heat-stable and heat-labile enterotoxin genes of Escherichia coli in diarrhoeic faecal samples of mithun (Bos frontalis) calves by polymerase chain reaction. Journal of Applied Microbiology 106(2):455458

Rigobelo, E. C., Gamez, H. J., Marin, J. M., Macedo, C., Ambrosin, J. A., and Ávila, F, A. (2006) Virulence factors of Escherichia coli isolated from diarrheic calves. Arquivo Brasileiro de Medicina Veterinária e Zootecnia 58(3): 305-310.

Sambrook, J., and Russell, D.W. (2001). Molecular cloning - a laboratory manual, $3^{\text {rd }}$ edition, Cold Spring Harbor Laboratory Press, Cold Spring Harbor.

Sandhu, K,S. and Gyles, C.L. (2002). Pathogenic shiga toxin-producing Escherichia coli in the intestine of calves. Canadian Journal of Veterinary Research 66: 65-72.

Sandra, N., Karina Mallardo., Annarosaria Marullo., Valentina Iovane., Luisa De Martino., and Ugo Pagnini (2010) Antibiotic susceptibility of haemolytic $E$. coli strains isolated from diarrhoeic faeces of buffalo calves. Italian Journal of Animal Science 9(1); 134.

Sundong-Bo, S., Rui, W.U., Xian-Jing, H.E., Shuang, W., YunCheng, L., Xu, H.A., Yue-Qiang, W., Ting-Ting, G.U.O., Guo-Jun, W.U. and Ke-Li, Y. (2011). Development of a multiplex PCR for diagnosis of Staphylococcus aureus, Escherichia coli and Bacillus cereus from cows with endometritis. Agricultural Sciences in China, 10(10): 1624-1629.

Toni, A., Chapman., Xi-Yang Wu., Idris Barchia., Karl A Bettelheim., Steven Driesen., Darren Trott., Mark Wilson., and James, J. C. Chin, (2006) 
Comparison of virulence gene profiles of Escherichia coli strains isolated from healthy and diarrheic swine. Applied and Environmental Microbiology 72(7): 4782-4795.

Vagh, A. A., and Jani, R. G. (2010) Prevalence and comparative studies of some major serotype of E.coli from cattle and buffalo calf scour. Veterinary World 3(10): 458-459.

WHO Scientific Working Group. Zoonotic non-O157 Shiga toxinproducing Escherichia coli (STEC), (1995). Report of a WHO Scientific Working Group meeting; 1998 Jun 2326; Berlin, Germany.

\section{How to cite this article:}

Srivani, M., Y. Narasimha Reddy, K.V. Subramanyam, M. Lakshman, T. Srinivasa Rao and Kavitha, K.L. 2020. Virulence Gene Profile and Serogroups of STEC in Diarrhoeic Buffalo Calves. Int.J.Curr.Microbiol.App.Sci. 9(09): 2696-2703. doi: https://doi.org/10.20546/ijcmas.2020.909.336 